\title{
The State and Prospects of Russia's Agri-Food Export to the Countries of the Eurasian Economic Union
}

\author{
S. V. Kiselev ${ }^{a, *}$ and R. A. Romashkin ${ }^{b}$ \\ ${ }^{a}$ Moscow State University, Moscow, 119991 Russia \\ ${ }^{b}$ Eurasian Center for Food Security, Moscow State University, Moscow, 119991 Russia \\ *e-mail: servikis@yandex.ru \\ Received July 27, 2020; revised October 15, 2020; accepted November 2, 2020
}

\begin{abstract}
The paper examines the features and main areas of the development of Russian exports of agrifood products to the countries of the Eurasian Economic Union. The complementarity of the agri-food trade of Russia with its partners in the EAEU is assessed. Products with comparative advantages are identified. Potential export values are indicated, and the prospects for Russian export supplies to the common agri-food market of the EAEU are analyzed.
\end{abstract}

Keywords: Eurasian Economic Union, agri-food products, complementarity of trade, revealed comparative advantages, export potential

DOI: $10.1134 / \mathrm{S} 1075700721020064$

Research objectives and methods. Export development is one of the priorities of the Russian agro-industrial policy. A decree of the President of the Russian Federation as of July 21, 2020 No. 474, On the National Development Goals of the Russian Federation for the Period up to 2030, established an indicator of real growth in the export of nonprimary nonenergy goods of at least $70 \%$ in 2030 compared to the level of 2020. Making allowance for the plans for export supplies of AIC products in the amount of 25 bln US dollars in 2020 [1], the target export of these products in 2030 will amount to 42.5 bln dollars $^{1}$. The calculations show that the established goal is achievable at average annual growth rates of supplies to foreign markets that must be not less than $105.5 \%$. This is a realistic indicator, given that the average annual growth rate of agrifood exports amounted to $109.5 \%$ in 2015-2019 and $115.2 \%$ in 2010-2014. Obviously, a further increase in agri-food exports will have a decaying character since each percent becomes more and more "significant" and more difficult to achieve with an increase in physical volumes of supplies.

In this regard, taking fundamental factors into account, it is very important to assess the dynamics

\footnotetext{
${ }^{1}$ The initially ambitious goal of increasing the export of Russian agricultural products to 45 bln USD in 2024 was set by Decree of the President of the Russian Federation as of May 7, 2018, No. 204, On National Goals and Strategic Objectives for the Development of the Russian Federation for the Period until 2024. Due to the impossibility of achieving this, the goal was adjusted by a Decree of the President of the Russian Federation as of July 21, 2020, No. 474 .
}

and characterize the potential of expanding agri-food supplies to the markets of the main trading partners, among which the countries of the Eurasian Economic Union $^{2}$ (EAEU) currently occupy an important place.

The goal of this study is to identify the features of Russian agri-food export to the EAEU countries and assess the potential for its development, making allowance for the dynamics of trade complementarity, the presence of comparative advantages and the potential for increasing supplies to the common agri-food market.

The study is based on the data of the Center for International $\mathrm{Trade}^{3}$ on the export and import of agrifood products by the EAEU countries [2] in accordance with the Commodity Nomenclature of Foreign Economic Activity (TN VED). The analysis of these data was carried out using the methods of descriptive statistics and the index approach in order to identify

\footnotetext{
2 The Eurasian Economic Union is an international organization for regional economic integration which was established by the Treaty on the Eurasian Economic Union as of May 29, 2014 and has been functioning since January 1, 2015. The Eurasian Economic Union replaced the Customs Union and Common Economic Space of Belarus, Kazakhstan and Russia. In 2015, EAEU was joined by Armenia and Kyrgyzstan.

${ }^{3}$ The International Trade Center (ITC) is a joint agency of the World Trade Organization and the United Nations (http://www.intracen.org/), which was established in 1964 to coordinate technical assistance in the area of trade. In accordance with the joint mandate of the WTO and the UN and through the United Nations Conference on Trade and Development (UNCTAD), the World Trade Center promotes the implementation of the regulatory, research and policy strategies of these organizations.
} 
the main trends, characterize quantitative and structural changes in the agri-food trade of Russia with partners in the EAEU and the rest of the world. To assess the degree of similarity between the commodity structure of Russian exports and the commodity structure of imports of EAEU partners, we calculated the complementarity indices of agri-food trade for groups 1-24 of the TN VED at the two-digit level for the period 2001-2019. Such indices are calculated for a specific year using the formula:

$$
T C I=\left[1-\left(\left|\frac{x_{i, s}}{X_{s}}-\frac{m_{i, d}}{M_{d}}\right|\right) \times \frac{1}{2}\right] \times 100 \%,
$$

where $i$ is a set of products (product groups of the TN VED at the two-digit level); $s$ is the exporting state; $d$ is the importing state; $m_{i d}$ is the import of a product $i$ by the state $d$ from all countries of the world; $M_{d}$ is the import of agri-food products by the state $d$ from all countries of the world; $x_{i s}$ is the export of the product $i$ by state $s$ to all countries of the world; $X_{s}$ is the export of agro-food products by the state $s$ to all countries of the world.

The complementarity indices range from $0 \%$ to $100 \%$. The minimum value indicates a complete lack of correspondence between the export and import profiles of the considered trading partners. The maximum value characterizes the complete coincidence in the structures of export and import of the partners.

The efficiency of production for various types of agri-food products in Russia relative to other countries of the world was characterized using the Balassa Revealed Comparative Advantage Index (RCA) [3]. This index is calculated using the formula:

$$
\mathrm{RCA}_{i}=\frac{x_{i} / X}{x_{w i} / X_{w}},
$$

where $x_{i}$ is the exports of the product $i$ of the country under consideration; $X$ is the total exports of the country under consideration; $x_{w i}$ is the world exports of the product $i ; X_{w}$ is the total world exports.

A country has a clear comparative advantage for a particular product if RCA $>1$. Generally, the higher the RCA value for a product, the larger the exportability of this product.

The potential values and prospects of Russian export supplies to the markets of the EAEU partners were identified using the estimates obtained by the International Trade Center. The methodology of such assessments is based on a structural model that determines the potential export values depending on the possible supply of the exporting country, the conditions of demand in existing and new markets, as well as bilateral relations between the trading partners under consideration [4]. In our opinion, the assessment of export potential using this methodology is conservative, since measurable parameters and components of export potential must be supplemented with other factors, which must be taken into account in analyzing the market of specific products. These include, for example, the willingness and ability to attract foreign direct investment, the availability of sectoral strategies and development programs. This methodology does not make allowance for export promotion policies either. Meanwhile, these measures can have a significant impact on the ability to export specific products.

For the products that are most in demand in the markets of the EAEU countries, the degree of implementation of the Russian export potential was calculated as the ratio of the actual supply of a certain product in 2019 to the potential supply of the same product, which were obtained on the basis of the World Trade Center Export Potential Map [5].

Results and discussion. The EAEU countries are important partners of Russia in agri-food trade. A sharp decline in export-import supplies took place at the initial stage of the integration association in 2015 (Fig. 1) due to the global financial crisis, which led to the depreciation of national currencies [6]. However, the following years saw a gradual recovery in trade. Since 2018, the value of Russian exports in the common agricultural market has exceeded the precrisis values of 2014 .

In 2019, Russian supplies of agricultural and food products to the EAEU states increased to 3.7 bln dollars, accounting for $14.9 \%$ of Russia's total agri-food exports. At the same time, imports to Russia from the EAEU countries increased to 5.1 bln dollars, and their share in the country's total agricultural and food imports reached $16.7 \%$. This took place against the background of a significant reduction in the presence of products from third countries on the Russian market, while exports from Russia increased under the influence of the devaluation of the national currency and food embargo [7]. These processes led to a noticeable improvement in the balance of agri-food trade of Russia with third countries, while some improvement in the balance of trade with partners in the EAEU has been observed only after 2017.

It should be noted that approximately $70 \%$ of Russian supplies to the common agri-food market of the EAEU are products with a relatively high degree of processing (Table 1).

These are mainly products of the food and processing industry (products from cereals, flour, starch or milk; flour confectionery; chocolate; tobacco products; processed fruits and vegetables; drinks; sugar and sugar confectionery; animal feed), which share in agri-food supplies to the common EAEU market is more than $50 \%$. The opposite situation is observed in Russian exports outside the EAEU, of which $70 \%$ consists of low-processed goods that include grain and fish. Fat and oil products (17.3\%) form the basis of high-value products' supplies to third countries. The share of meat and dairy products is increasing. Meanwhile, the value of their exports to third countries is 


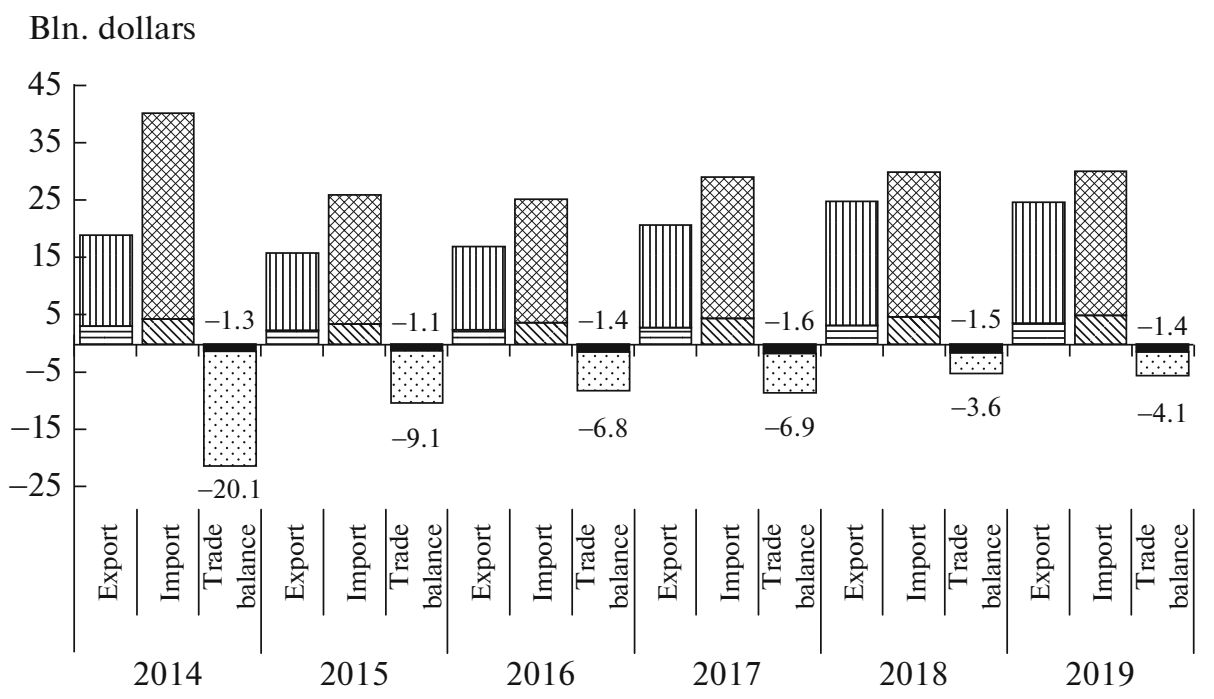

Fig. 1. Russia's foreign trade in agri-food products in 2014-2019: 目 export to the EAEU countries; 而 export to other countries; $\square$ import from the EAEU countries; import from other countries; $\square$ the balance of trade with the EAEU countries; 9 the balance of trade with other countries.

Source: the figure was built based on the data from [2].

two times higher than supplies to partners in the EAEU.

Among the EAEU countries, the main partners of Russia in terms of the values of agri-food trade are Kazakhstan and Belarus (Table 2): the shares of these countries in the structure of Russian exports to the EAEU market in 2019 amounted to $49 \%$ and $37 \%$, respectively. Moreover, supplies to the Belarusian market provided more than half of the growth in Russian exports over the period under consideration.

In addition, Belarus is a leading supplier of agricultural and food products to the Russian market within not only the EAEU, but also all countries of the world. The value of Russia's agri-food imports from Belarus exceeds imports from China by 2.5 times and imports from Brazil by 2.8 times. As a result, the negative balance of Russia's aggregate agri-food trade $(-5.5$ bln dollars) is formed by $52 \%$ due to not quite balanced export-import operations with Belarus. This situation is largely due to the relatively high level of state support for agriculture in Belarus, which is 2.5-3 times higher than the level of support for agricultural production in Russia [9].

The starting point for identifying promising areas for the development of Russian exports and strengthening trade relations within the EAEU is to assess the dynamics of the complementarity of agri-food trade. The calculations of the corresponding indicators for the period from 2001 to 2019 reflect the general trend towards a decrease in the degree to which the structure

Table 1. Values and structure of Russian exports to the EAEU countries and outside the EAEU for the main groups of agrifood products in 2014 and 2019

\begin{tabular}{|c|c|c|c|c|c|c|c|c|}
\hline \multirow{3}{*}{$\begin{array}{l}\text { Groups of agri-food products } \\
\text { in accordance with the "Export of AIC } \\
\text { Products" Federal Project [8] }\end{array}$} & \multicolumn{4}{|c|}{ Exports to the EAEU countries } & \multicolumn{4}{|c|}{ Exports outside the EAEU } \\
\hline & \multicolumn{2}{|c|}{ values, bln USD } & \multicolumn{2}{|c|}{ structure, $\%$} & \multicolumn{2}{|c|}{ values, bln USD } & \multicolumn{2}{|c|}{ structure, $\%$} \\
\hline & 2014 & 2019 & 2014 & 2019 & 2014 & 2019 & 2014 & 2019 \\
\hline Grain & 0.1 & 0.3 & 2.8 & 6.9 & 7.0 & 7.7 & 43.7 & 36.2 \\
\hline Fish and seafood & 0.1 & 0.1 & 3.9 & 3.6 & 2.9 & 4.7 & 18.0 & 22.2 \\
\hline Fat and oil products & 0.4 & 0.4 & 12.6 & 10.4 & 2.6 & 3.7 & 16.5 & 17.3 \\
\hline Meat and dairy products & 0.3 & 0.3 & 9.0 & 7.5 & 0.1 & 0.5 & 0.7 & 2.6 \\
\hline Food and processing industry products & 1.7 & 1.8 & 54.3 & 50.1 & 1.9 & 2.2 & 12.1 & 10.4 \\
\hline Other agricultural products & 0.5 & 0.8 & 17.4 & 21.4 & 1.4 & 2.4 & 9.0 & 11.4 \\
\hline Agricultural products, total & 3.1 & 3.7 & 100.0 & 100.0 & 16.0 & 21.2 & 100.0 & 100.0 \\
\hline
\end{tabular}

Source: the calculations were made based on the data of [2]. 
Table 2. Russia's trade in agri-food products with the EAEU countries in 2014 and 2019, mln dollars

\begin{tabular}{l|r|r|r|r|r|r|r|r|r}
\hline \multirow{2}{*}{ Country } & \multicolumn{3}{|c|}{ Exports } & \multicolumn{3}{c|}{ Imports } & \multicolumn{3}{c}{ Balance(net export) } \\
\cline { 2 - 9 } & 2014 & 2019 & growth & 2014 & 2019 & growth & 2014 & 2019 & change \\
\hline Armenia & 163 & 279 & 116 & 244 & 390 & 146 & -80 & -111 & -31 \\
Belarus & 1017 & 1353 & 336 & 3766 & 4231 & 465 & -2749 & -2878 & -129 \\
Kazakhstan & 1695 & 1808 & 113 & 308 & 374 & 66 & 1387 & 1434 & 47 \\
Kyrgyzstan & 217 & 250 & 33 & 34 & 73 & 39 & 183 & 177 & -6 \\
Total & 3092 & 3691 & 598 & 4351 & 5068 & 717 & -1259 & -1377 & -119 \\
\hline
\end{tabular}

Source: the calculations were made based on the data of [2].

of Russian exports corresponds to the import profiles of the EAEU partners (Fig. 2). Meanwhile, a sharp increase in complementarity in some years is first of all due to a decrease in the share of grain crops and increase in the share of processed products in the structure of agri-food exports of Russia. In this regard, it should be noted that reaching the target export values established in the Export of AIC Products Federal Project [8] will lead to a reduction in the share of grain in the value of Russian agri-food exports to $25 \%$ and an increase in the share of medium and high value added products to $50 \%$. This will help to increase the indicators of trade complementarity between Russia and the rest of the EAEU countries. Such an increase may have already begun. In 2019, the complementarity indices for Russia's trade with Belarus and Kazakhstan reached the precrisis level, which indicates an improvement in the conditions for Russia to implement the export potential of agri-food products in the common EAEU market.

Out of 190 commodity items of agri-food products (at the four-digit level for groups 1-24 of the TN VED) that are exported by Russia to the EAEU countries, only 25 items are characterized by the revealed

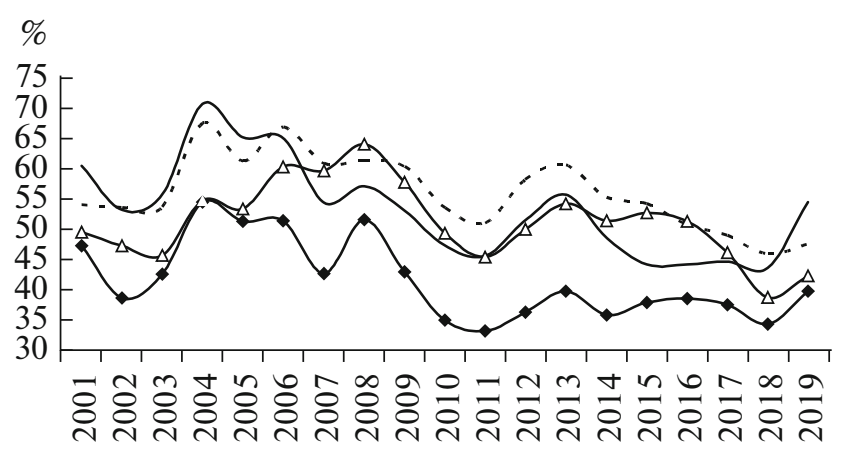

Year

Fig. 2. Complementarity index for Russia's agri-food trade with partners in the EAEU in 2001-2019:

-- - Russia-Armenia; - Russia-Belarus; - - RussiaKazakhstan; $-\triangle-$ Russia-Kyrgyzstan

Source: the figure was built based of the data from [2] for groups 1-24 of the TN VED at the two-digit level. comparative advantages. According to the RCA index, the list of export goods in the production of which Russia has a comparative advantage includes five types of cereals (wheat, buckwheat, barley, oats and rye), frozen fish, aquatic invertebrates, flax and sunflower seeds, vegetable oils (rapeseed, sunflower, soy oils), margarine, chocolate and other products (Table 3). The value of the export of such goods to the EAEU countries reached 1.1 bln dollars in 2019. More than $75 \%$ of this export was accounted for by chocolate, sunflower oil, wheat, tobacco and its substitutes, and margarine. The absence or low values of supplies among a significant part of the remaining commodity items with revealed comparative advantages indicate constraints on demand in the EAEU countries. Exports for a number of such commodity items (soybean oil, wheat gluten, starch residues, beet pulp, molasses, aquatic invertebrates, glands and other animal products) are not susceptible to changes in RCA indices. In general, the share of exports of Russian products that are characterized by the revealed comparative advantages in the total agri-food exports of Russia to the EAEU countries amounted to approximately $30 \%$ in 2019.

More than two-thirds of the supplies of Russian agri-food products to the markets of the EAEU countries are accounted for by goods for which comparative advantages have not yet become apparent. If we take the supplies exceeding $100 \mathrm{mln}$ dollars as a cut-off line, then such goods include bakery and flour confectionery, animal feed, sugar, other food products (protein concentrates, syrups, chewing gum, mixtures of vitamins and minerals), cigarettes and water with added sweeteners. In 2019, the export of these goods amounted to $887 \mathrm{mln}$ dollars, or $55 \%$ in the list of TOP-10 commodity items in terms of export values of Russian agri-food products to the EAEU (Table 4).

It is also necessary to note the relatively high growth rates of supplies to the markets of the EAEU countries for Russian agri-food products, the comparative advantages of which have not become apparent. Compared to 2010, the supplies of such goods have increased 19 times, while the exports of products with revealed comparative advantages have increased eight times. This gap is due, on the one hand, to a relatively 
Table 3. Dynamics of RCA indices and supplies to the markets of the EAEU countries for the Russian agri-food products characterized by revealed comparative advantages in 2010-2019

\begin{tabular}{|c|c|c|c|c|c|c|c|c|c|}
\hline \multirow{2}{*}{\multicolumn{2}{|c|}{ TN VED code and name of a commodity item }} & \multicolumn{4}{|c|}{ RCA Index } & \multicolumn{4}{|c|}{$\begin{array}{l}\text { Values of Russian exports to the EAEU } \\
\text { countries, mln USD }\end{array}$} \\
\hline & & 2010 & 2014 & 2018 & 2019 & 2010 & 2014 & 2018 & 2019 \\
\hline \multicolumn{10}{|c|}{$\begin{array}{l}\text { TOP- } 5 \text { commodity items characterized by revealed } \\
\text { comparative advantages in } 2019\end{array}$} \\
\hline 1806 & Chocolate & 0.5 & 0.9 & 0.9 & 1.1 & 40.3 & 376 & 255 & 267 \\
\hline 1512 & Sunflower oil & 2.0 & 5.5 & 6.5 & 8.6 & 32.1 & 206 & 189 & 201 \\
\hline 1001 & Wheat & 2.4 & 4.3 & 8.9 & 7.1 & 43.6 & 48 & 95 & 167 \\
\hline 2403 & Processed tobacco and its substitutes & 0.8 & 1.5 & 1.2 & 1.4 & 0.1 & 61 & 60 & 101 \\
\hline 1517 & Margarine & 0.7 & 1.2 & 1.4 & 1.6 & 7.5 & 73 & 87 & 97 \\
\hline \multicolumn{2}{|c|}{$\begin{array}{l}\text { Total (for the above TOP- } 5 \text { commodity items } \\
\text { Other commodity items }\end{array}$} & - & - & - & - & 124 & 765 & 687 & 834 \\
\hline 0303 & Frozen fish & 3.6 & 3.1 & 4.4 & 4.4 & 2.8 & 65 & 58 & 59 \\
\hline 2306 & Oilcake & 1.3 & 2.3 & 1.8 & 2.7 & 2.2 & 2 & 32 & 50 \\
\hline 1003 & Barley & 1.5 & 3.8 & 5.8 & 5.0 & 2.5 & 2 & 23 & 47 \\
\hline 1206 & Sunflower seeds & 0.0 & 0.5 & 0.5 & 2.5 & 0.8 & 17 & 31 & 46 \\
\hline 1104 & Cereal grain processed by other methods & 0.7 & 1.9 & 1.6 & 2.1 & 1.2 & 15 & 19 & 23 \\
\hline 2102 & Yeast & 0.2 & 0.6 & 1.6 & 1.6 & 0.3 & 16 & 17 & 17 \\
\hline 0713 & Dried leguminous vegetables & 0.2 & 0.8 & 1.5 & 1.8 & 0.8 & 4 & 6 & 7 \\
\hline 0306 & Crustaceans & 0.5 & 0.8 & 1.8 & 2.4 & 0.0 & 4 & 5 & 7 \\
\hline 1204 & Flax seeds & 2.8 & 5.9 & 8.0 & 10.9 & 0.0 & 1 & 1 & 4 \\
\hline 1514 & Rapeseed oil & 0.6 & 1.6 & 2.5 & 3.4 & 0.0 & 6 & 2 & 4 \\
\hline 1008 & Buckwheat & 0.1 & 0.9 & 1.3 & 1.4 & 0.1 & 1 & 2 & 3 \\
\hline 1004 & Oats & 0.0 & 0.1 & 0.5 & 1.2 & 0.0 & 0 & 2 & 3 \\
\hline 2302 & Bran & 0.8 & 1.7 & 3.2 & 3.6 & 0.0 & 0 & 1 & 2 \\
\hline 1507 & Soybean oil & 0.6 & 1.2 & 2.0 & 2.1 & 0.4 & 2 & 2 & 2 \\
\hline 1002 & Rye & 0.1 & 1.6 & 4.7 & 1.4 & 0.0 & 0 & 6 & 1 \\
\hline 1109 & Wheat gluten & 0.7 & 1.0 & 1.4 & 1.6 & 0.0 & 1 & 1 & 1 \\
\hline 2303 & Residues from starch production, beet pulp & 0.5 & 0.9 & 1.6 & 1.9 & 0.0 & 0 & 0 & 0 \\
\hline 1703 & Molasses & 0.6 & 2.3 & 2.9 & 2.9 & 0.0 & 0 & 1 & 0 \\
\hline 0308 & $\begin{array}{l}\text { Aquatic invertebrates, except crusta- } \\
\text { ceans and molluscs }\end{array}$ & 0.0 & 0.9 & 1.8 & 2.0 & 0.0 & 0 & 0 & 0 \\
\hline 0510 & Glands and other animal products & 0.7 & 1.7 & 1.7 & 2.6 & 0.0 & 0 & 0 & 0 \\
\hline \multicolumn{2}{|l|}{ Total } & Total & - & - & - & 135 & 902 & 896 & 1109 \\
\hline
\end{tabular}

Source: the calculations were made based on the data of [2].

small number of commodity items characterized by high values of the RCA index and, on the other hand, to the key role played by the EAEU partners in the possibility of strengthening Russia's export potential for goods without revealed comparative advantages. In this regard, it should be emphasized that the absence of customs barriers, the presence of unified technical regulations, phytosanitary, veterinary and sanitary requirements, and the proximity of sales markets provide Russian exporters with certain advantages to gain a foothold in the markets of the EAEU countries and replace imports from the rest of the world. In other words, as applied to the common EAEU market, the assessments of the revealed comparative advantages in world trade do not reflect the peculiarities of intraregional trade, which are determined by the specific socioeconomic characteristics of the group of countries under consideration and the advantages for the development of mutual supplies created by regional economic integration. Based on this, it can be assumed that the RCA index may not quite accurately reflect the export capabilities of individual countries 
Table 4. Dynamics of RCA indices and supplies to the markets of the EAEU countries for the Russian agri-food products for which comparative advantages did not become apparent in 2010-2019

\begin{tabular}{|c|c|c|c|c|c|c|c|c|c|}
\hline \multirow{2}{*}{\multicolumn{2}{|c|}{$\begin{array}{l}\text { TN VED code and name of a commodity } \\
\text { item }\end{array}$}} & \multicolumn{4}{|c|}{ RCA index } & \multicolumn{4}{|c|}{$\begin{array}{l}\text { Values of Russian exports to the EAEU } \\
\text { countries, mln USD }\end{array}$} \\
\hline & & 2010 & 2014 & 2018 & 2019 & 2010 & 2014 & 2018 & 2019 \\
\hline \multicolumn{10}{|c|}{$\begin{array}{l}\text { Commodity items for which the value } \\
\text { of supplies exceeded } 100 \text { mln USD in } 2019\end{array}$} \\
\hline 1905 & $\begin{array}{l}\text { Bakery and flour confectionery } \\
\text { products }\end{array}$ & 0.2 & 0.4 & 0.4 & 0.5 & 11 & 245 & 240 & 267 \\
\hline 2309 & Animal feed & 0.1 & 0.2 & 0.2 & 0.3 & 2 & 101 & 106 & 130 \\
\hline 1701 & Sugar & 0.0 & 0.0 & 0.3 & 0.6 & 0 & 3 & 107 & 129 \\
\hline 2106 & Other food products & 0.2 & 0.2 & 0.2 & 0.3 & 5 & 112 & 110 & 123 \\
\hline 2402 & Cigarettes & 0.5 & 0.9 & 0.5 & 0.5 & 28 & 147 & 124 & 119 \\
\hline 2202 & Waters with added sweeteners & 0.1 & 0.2 & 0.3 & 0.4 & 9 & 47 & 91 & 119 \\
\hline \multicolumn{2}{|c|}{ Total (for the above commodity items) } & - & - & - & - & 55 & 655 & 778 & 887 \\
\hline \multicolumn{2}{|c|}{ Other commodity items } & & & & & 80 & 1535 & 1587 & 1694 \\
\hline \multicolumn{2}{|c|}{ Total } & - & - & - & - & 135 & 2190 & 2365 & 2581 \\
\hline
\end{tabular}

Source: the calculations were made based on the data of [2].

in analyzing relatively small customs unions or other regional integration associations.

In view of the above, it is logical to pose the question of the potential values and prospects of Russian export supplies to the markets of the EAEU partners. To answer this question, we used the estimates obtained by the World Trade Center [5]. In accordance with the methodology developed by this center, the level of Russia's implementation of its export potential in the markets of the EAEU countries in relation to the volume of exports of the most demanded food products ${ }^{4}$ in 2019 is $88 \%$ (Table 5). Of the considered commodity items, the export potential has been fully implemented for the supply of water with added sweeteners. Actual export values are close to potential ones for other food products $(99 \%)$, animal feed (98\%). A high level of implementation of export potential is noted for bakery and flour confectionery (94\%), sugar (93\%), and wheat $(91 \%)$. The largest gaps between potential and actual export values are observed for margarine, sunflower oil, and chocolate. These are products with identified comparative advantages. Reaching the potential volumes of supplies to the EAEU countries will increase Russian exports of chocolate, sunflower oil and margarine by 70, 53 and $32 \mathrm{mln}$ dollars, respectively.

As regards particular destinations, the largest export potential of Russia for the considered products has been implemented in the market of Armenia $(97 \%)$, and the least one has been achieved in the market of Kyrgyzstan (65\%). The actual supplies to Belarus and Kazakhstan lag behind the potential ones

\footnotetext{
${ }^{4}$ That is, those that are in TOP-10 in terms of export value.
}

by approximately $10 \%$. The markets of Kazakhstan and Kyrgyzstan are the most capacious for increasing exports from Russia. Reaching the potential values of supplies for the goods under consideration will increase Russian exports to Kazakhstan and Kyrgyzstan by 82 and 70 mln dollars, respectively. In addition, the Kazakhstan market is the most promising in the long term, since the per capita GDP in the republic is the closest to the Russian indicator, and the size of the population in Kazakhstan almost corresponds to the total population of Armenia, Belarus, and Kyrgyzstan.

Belarus appears to be the most difficult partner for Russia in terms of building long-term trade and economic relations in order to improve the balance of agri-food trade. The limited potential for increasing the presence of Russian agri-food products in the Belarusian market and the policy of import substitution conducted by Russia indicate the advisability of developing trade relations based on the partners building of joint value chains, primarily for exporting products to third countries. This approach will strengthen trade and economic ties and ensure the progressive development of integration and cooperation processes in the agro-industrial sector of the two countries.

At present, Russia is close to fully implementing the available potential for increasing the supply of agri-food products to the markets of the EAEU countries. For the most demanded food products, it amounts to $203 \mathrm{mln}$ dollars, or $12 \%$ of the supply value in 2019. As the target export values of 42.5 bln dollars are achieved by 2030, the share of supplies to the EAEU market in the structure of Russian agri-food exports will decrease from 14.9 to $9.2 \%$. However, the 
Table 5. Implementation of Russian export potential in the markets of the EAEU countries in relation to the values of supplies of the most demanded food products in 2019

\begin{tabular}{|c|c|c|c|c|c|c|c|c|c|c|c|c|c|c|c|}
\hline \multirow[b]{2}{*}{$\begin{array}{l}\text { Commodity item } \\
\text { name }\end{array}$} & \multicolumn{5}{|c|}{ Export values, mln USD } & \multicolumn{5}{|c|}{$\begin{array}{l}\text { Unutilized export potential, } \mathrm{mln} \\
\text { USD }\end{array}$} & \multicolumn{5}{|c|}{$\begin{array}{l}\text { Implementation of export } \\
\text { potential, } \%\end{array}$} \\
\hline & 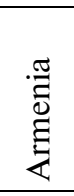 & 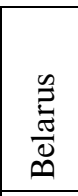 & 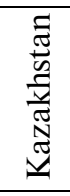 & 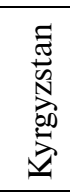 & 긴 & 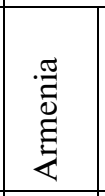 & 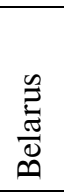 & 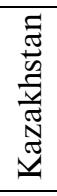 & 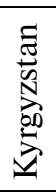 & 离 & 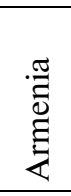 & 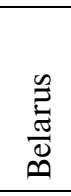 & 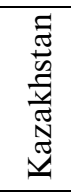 & 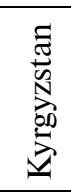 & 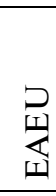 \\
\hline Chocolate & 27 & 68 & 137 & 36 & 267 & 1 & 7 & 46 & 16 & 70 & 96 & 91 & 75 & 70 & 79 \\
\hline $\begin{array}{l}\text { Bakery and flour con- } \\
\text { fectionery products }\end{array}$ & 13 & 86 & 139 & 29 & 267 & - & 1 & 13 & 4 & 18 & 100 & 99 & 91 & 89 & 94 \\
\hline Sunflower oil & 20 & 66 & 86 & 29 & 201 & 1 & 13 & 23 & 17 & 53 & 94 & 84 & 79 & 63 & 79 \\
\hline Wheat & 59 & 54 & 51 & 4 & 167 & 2 & - & - & 15 & 17 & 96 & 100 & 100 & 21 & 91 \\
\hline Animal feed & 6 & 63 & 57 & 3 & 130 & - & 2 & - & - & 2 & 100 & 97 & 100 & 100 & 98 \\
\hline Sugar & 4 & 31 & 90 & 5 & 129 & 0.4 & - & - & 9 & 9 & 90 & 100 & 100 & 37 & 93 \\
\hline $\begin{array}{l}\text { Other food prod- } \\
\text { ucts* }\end{array}$ & 8 & 42 & 66 & 7 & 123 & - & - & - & 1 & 1 & 100 & 100 & 100 & 83 & 99 \\
\hline $\begin{array}{l}\text { Water with added } \\
\text { sweeteners }\end{array}$ & 6 & 26 & 73 & 14 & 119 & - & - & - & - & - & 100 & 100 & 100 & 100 & 100 \\
\hline Margarine & 16 & 24 & 52 & 6 & 97 & 0.1 & 23 & - & 9 & 32 & 99 & 51 & 100 & 40 & 75 \\
\hline Total & 157 & 459 & 751 & 132 & 1500 & 5 & 46 & 82 & 70 & 203 & 97 & 91 & 90 & 65 & 88 \\
\hline
\end{tabular}

* Protein concentrates, syrups, chewing gum, mixtures of vitamins and minerals.

Source: the information was compiled and calculated on the basis of the data of $[2,5]$.

opportunities for not only expanding, but also maintaining the achieved export values in the existing realities are undermined by the negative dynamics of demand in the EAEU member states, which is exacerbated by the economic decline due to the COVID-19 pandemic. It is also important to take into account the high volatility of the ruble exchange rate. Its devaluation can reduce export indicators in dollar terms in case of increase in physical volumes. In addition, when the exchange rate of the national currency falls, the Russian agro-industrial complex faces the challenge of ensuring the competitiveness of domestic products due to the high dependence on imported resources, means of production, and technologies.

Conclusions. The study has shown that the EAEU countries continue to remain important partners of Russia in agri-food trade. The structure of Russian supplies to the common EAEU market is dominated by products with a high degree of processing. The established positive dynamics of trade complementarity indices testifies to improved conditions for Russia to implement its export potential in the EAEU.

More than two-thirds of the supplies of Russian agri-food products to the EAEU countries are accounted for by goods for which comparative advantages have not been revealed. In this regard, the RCA index as applied to Russia's partners in the EAEU with consideration for the low capacity of their markets does not allow an accurate assessment of the prospects for export development. The peculiarities of mutual trade of the EAEU countries with their specific socioeconomic characteristics and benefits of regional economic integration provide Russian exporters with certain advantages in the partner markets.

The greatest potential for growth in Russian supplies to the common EAEU market is possessed by products with revealed comparative advantages, such as margarine, sunflower oil, and chocolate. As regards the particular destinations, the markets of Kazakhstan and Kyrgyzstan are the most capacious for increasing Russian exports.

The imbalance of export-import operations with Belarus necessitates the development of trade ties based on the partners building joint value chains for exporting agri-food products to third countries, including China and the European Union. This approach will reduce the tension in bilateral trade relations and will contribute to the sustainable development of the national agro-industrial complexes.

In general, the export potential of Russia for agrifood products in the EAEU countries is characterized by a high degree of implementation. Restraining factors are the negative dynamics of demand in the member states and the need to ensure the long-term competitiveness of domestic products in the face of ruble depreciation. 


\section{FUNDING}

The study was carried out with the support of the Russian Foundation for Basic Research within the framework of scientific project No. 20-010-00639A.

\section{CONFLICT OF INTEREST}

The authors declare that they have no conflicts of interest.

\section{REFERENCES}

1. D. Patrushev, Head of the Ministry of Agriculture: Export of Agricultural Products from Russia in 2020 Will Amount to $\$ 25$ billion (2020). https://futurerussia.gov.ru/nacionalnye-proekty/glava-minselhoza-eksport-produkciiapk-iz-rossii-v-2020-godu-sostavit25-mlrd.

2. Trade Map Database. International Trade Center. Trade Statistics (2020). https://www.trademap.org/Index.aspx.

3. B. Balassa, "Trade liberalization and 'revealed' comparative advantage," Manchester Sch. 33 (2), 99-123 (1965). http://onlinelibrary.wiley.com/doi/abs/10.1111/ j.1467-9957.1965.tb00050.x.

4. Yvan Decreux and Julia Spies, Export Potential Assessments, A Methodology to Identify Export Opportuni- ties for Developing Countries (2016). http://umbraco.exportpotential.intracen.org/media/1089/epamethodology_141216.pdf.

5. Export Potential Map (Int. Trade Center, 2020). https://exportpotential.intracen.org/en/.

6. S. V. Kiselev and R. A. Romashkin, "Agricultural development in the Eurasian Economic Union: Achievements, challenges, and prospects," APK: Ekon., Upr., No. 1, 74-90 (2020).

7. S. Kiselev, R. Romashkin, and A. Soldatova, "Comparative advantages and complementarity of agri-food trade between the EU and Russia," in Proceedings of the 29th International Scientific Conference Agrarian Perspectives XXIX. Trends and Challenges of Agrarian Sector (Prague, 2020), pp. 159-166.

8. Passport of the Federal Project Export of Agricultural Products (Ministry of Agriculture of Russia, 2018). https://mcx.gov.ru/upload/iblock/013/013f266cee8d39bce5ca867381ff0da1.pdf.

9. S. V. Kiselev, A. S. Strokov, and A. Yu. Belugin, "Consequences of the possible accession of the Republic of Belarus to the WTO: Scenarios for agriculture," Torg. Polit., No. 1, 128-143 (2015).

Translated by L. Solovyova 